\title{
Film Coated Extended Release Tablet Dosage Form
}

National Cancer Institute

\section{Source}

National Cancer Institute. Film Coated Extended Release Tablet Dosage Form. NCI

Thesaurus. Code C42930.

A tablet covered with a thin layer of water soluble or insoluble polymer and is designed to release active and/or inert ing redient(s) at a controlled, prolonged rate so as to reduce dosing frequency. 